Jurnal Akuntabilitas Manajemen Pendidikan

Volume 9, No. 1, April 2021 (98-112)

Online: http://journal.uny.ac.id/index.php/jamp

\title{
School principal's role in increasing teachers' pedagogical and professional competence in elementary schools in Indonesia
}

\author{
Ahmad Ansori, Suyatno *, Dwi Sulisworo \\ Universitas Ahmad Dahlan \\ J1. Kapas No. 9, Semaki, Umbulharjo, Kota Yogyakarta, Daerah Istimewa Yogyakarta 55166, Indonesia. \\ * Corresponding Author. Email: suyatno@pgsd.uad.ac.id
}

\section{ARTICLE INFO}

\section{Article History}

Received:

10 November 2020;

Revised:

27 April 2021;

Accepted:

3 May 2021

Available online:

3 May 2021

\section{Keywords}

school principal;

professional

competence;

pedagogical

competence;

Muhammadiyah

elementary school.

\begin{abstract}
A principal has an important role in improving teacher's competence. This qualitative research with a case study approach aimed to reveal school principal's role in increasing teacher pedagogical and professional competence in Muhammadiyah elementary school of Macanan, Sleman and Muhammadiyah elementary school of AlMujahidin, Gunungkidul. The research subject was the school principal and teachers. Data were collected through observation, interview, and documentation, then were analyzed using the stages of data collection, data reduction, data representation, and conclusion drawing. The results show that the role of the school principal in increasing teacher pedagogical and professional competence was as a manager, leader, and innovator. As a manager, the school principal planned the program by detailing educators' need and education staff, planning curriculum, and planning a policy for adding the subject of guidance and counselling. As a leader, the school principal set the targets regarding class management and arranged a briefing, while as an innovator, the school principal emphasized the importance of innovation of information technology-based learning and class management. The three roles of the school principal impacted on teacher competence in conducting fun and meaningful learning, class management, the use of information technology in learning, the mastery of the material and student development. This research finding recommends Indonesia's educational stakeholders to formulate the teacher's competence development program.
\end{abstract}

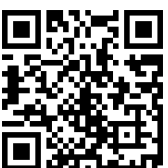

This is an open access article under the CC-BY-SA license.

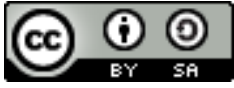

How to cite:

Ansori, A., Suyatno, S., \& Sulisworo, D. (2021). School principal's role in increasing teachers' pedagogical and professional competence in elementary schools in Indonesia. Jurnal Akuntabilitas Manajemen Pendidikan, 9(1), 98-112. doi:https://doi.org/10.21831/jamp.v9i1.35635 


\section{INTRODUCTION}

The quality of education in school is mostly determined by teacher pedagogical and professional competence. This mastery enables the teacher to deliver the materials interactively, interestingly, and appropriately to student learning and development. A qualified teacher can create an effective and interesting learning environment, also can manage the class well, therefore, the student's learning process can run optimally. The teacher is a critical success factor of the students in the class (Gumus, 2013; Marzano et al., 2001). Moreover, it is required serious and comprehensive efforts in improving pedagogical competence and teacher's professional competence.

Many researches show that one of the efforts that can be carried out to improve pedagogical competence and teacher's professional competence is through the optimization of the principal leadership (Hamalik, 2010; Lassila et al., 2017; Leithwood \& Jantzi, 2006; Tschannen-Moran, 2009). Boon (2017) stated that in order the competence is improved, the teacher requires the assistance of the principal, therefore, a principal must able to be a role model as a leader, manager, educator, administrator, and innovator. A principal who is able to carry out the role well can improve teacher's performance and satisfaction (Boyce \& Bowers, 2018). Other research found a positive relationship between principal leadership and teacher professionalism in instruction (Liu \& Hallinger, 2018; Sehgal et al., 2017; Liu \& Hallinger, 2018; Qian \& Walker, 2013; Zheng et al., 2019). Teachers led by school principals who can apply good leadership will last longer in their work (Player et al., 2017). On the other hand, the school which shows high leadership score also has a higher teacher educational level, self-esteem, and work satisfaction level (Paletta et al., 2017). The quality of support provided by the principal's leadership increases work commitment and teacher contributions to the school (Hulpia et al., 2011). The principal' leadership affected teacher effectiveness by articulate a learning vision that inspired the school to set goals and challenges that will be achieved, make student's and teacher's performance standard clear, assist the learning and teacher development, and train the teachers to succeed (Çalik et al., 2012; Domsch, 2009). The change in leadership competencies of principals affects teacher beliefs. If the leadership competencies of the principal change are adequate, the confidence of the teacher to carry out learning will successfully increase (Kin et al., 2018).

In Indonesia, the practice of principal's leadership has developed according to the dynamics of the times and relates to the prevailing leadership theory. In this current reformation era, educational leadership in Indonesia has been changed drastically so that the principal is demanded to fulfil specific standard, participate in systematic training, and derive a grade from district and city government (Sumintono, 2017). In 2007, the ministry of education and culture issued a Ministerial Regulation Number 13/2007 which states that school principals must have personal, managerial, entrepreneurial, social, and supervisory competencies. According to the regulation of the ministry of education and culture Number 6/2018 Chapter VI article 15, a principal's workload is fully to carry out the managerial main task, entrepreneurial development, and supervision of teachers and educational personnel. The setting of workload is aimed to make the principal can focus on and optimize in developing school and improve school quality based on eight national education standard.

Muhammadiyah school is one of the private school models developed in Indonesia. Organizationally, this school is under Muhammadiyah community organization. In the managerial implementation, apart from being based in the Muhammadiyah organization, this school is under the auspices of the Ministry of Education and Culture (Muttaqin et al., 2019). Along with adopting a national curriculum, Muhammadiyah school also enriches the curriculum with the teaching of Islam and Muhammadiyah knowledge. In the educational implementation, Muhammadiyah uses advanced Islamic core values as a way of religion in understanding Islamic teaching which is responsive to the advancement of the times. By implementing advanced Islamic values, it is expected that the education process of Muhammadiyah school can apply the advanced character towards their students, therefore, students have global knowledge, are up to date in the technology information development, and live in modernity, but hold on the values based on the teachings of Al-Qur'an (Hefner, 2008; Setiawan, 2008).

Muhammadiyah elementary school of Macanan and Muhammadiyah elementary school of AlMujahidin is two examples of Muhammadiyah elementary school in Yogyakarta Regional Regency which is grown rapidly and is favorite privat primary school in each region. Muhammadiyah elementary school (sekolah dasar or SD) of Macanan is located at the rural area of Macanan, Ngemplak 
sub-district, East Sleman regency. Even though this location is in rural areas, this Muhammadiyah elementary school of Macanan reaches out to students from several surrounding sub-districts. Meanwhile, SD Muhammadiyah Al-Mujahidin Wonosari is located in a strategic area, downtown Gunungkidul Regency. The similarities of these two schools are that both schools have been growing rapidly in the last three years. The development of both schools can be seen by the improvements of the trends or society interest to send their children to these two schools. The difference, meanwhile, is a geographical location that one is located in the rural areas and another is in the downtown of the district. According to the pre-research of both school, the same tendencies show that the advancement and development of both schools are influenced by the principal role in improving teacher competency, especially pedagogical and professional competency. Both principals have been prioritized the development of the competencies since the improvement of teacher's competencies leads to effective learning that leads students to produce achievements. The number of achievements ultimately becomes the appeals of schools for societies to send their children to both schools.

Based on the background, this research aims to study the principal role in improving teacher's pedagogical and professional competency. This research is crucial to enrich the literature, especially about the leadership role of the principals in improving teacher's competencies since the literature on this study is not widely discussed in Indonesian contexts. In this research, the researchers use qualitative research by a case study (Creswell, 2013). To collect the data, the researchers were assisted by open interview guidelines. This finding is expected to provide scientific knowledge on how the school principal role to be more successful in increasing pedagogical and professional competence.

\section{The Development of Teacher's Competencies in Indonesia}

A teacher is a person who supports and facilitates students' knowledge (Djamarah, 2010). Teacher role increasingly expands. The teacher's duty as an educator not only educate students' intelligence through the transfer of knowledge carried out routinely in the classroom but also as a guide, coach, student's talent, interest, ability towards the maximum they can reach in order to be an adult human capable of mastering science and developing it for the welfare of life. A competent teacher will be more capable create effective and fun learning environment and more capable of managing the class so that students' learning process is more optimally. Competence is a set of intelligent actions, skills, and rational behaviours to be able to do work to achieve the goals (Nasution, 2011; Naim, 2016; Majid, 2014; Usman, 2013). Nemet (2018) indicated that teachers' competencies can be divided into four main areas: pedagogical, professional-subject, organizational, and communication-reflexive. In Indonesia, Law Number 14 of 2005 also confirms that teachers must have pedagogical, professional, social, and personality-based competences. Although all instructional facets are important, pedagogical and professional capacity are especially key in the Indonesian context.

Quantitatively, the total of teachers in Indonesia is adequate, however, in contrast, the good quality of teachers competencies is still limited. Several indicators of the problems are, for examples, that the knowledge background and the subjects they taught are not matching. The problems interfere with the learning process so it cannot run optimally, also students do not acquire a qualified learning service. The further impact of this fact is the low quality of educational institution alumni in the country. UNDP reported that in 2013, the index of human development in Indonesia ranked 121 out of 185 countries. The quality of Indonesian is determined by the quality of the education, while the quality of education is determined by learning quality. The quality of the teachers is a critical factor of learning quality. Therefore, teacher competency is an important factor in determining the quality of education in Indonesia.

Competent teachers will be able to carry out quality learning, manage the class well, and serve the students according to the needs, and create a conducive learning environment. With this condition, the learning achievement obtained is high. The research result also shows that teacher competency can influence about $50 \%$ of student's learning result. The urgency of teacher competency is the quality of the teachers who has a very important position in determining the quality of education in the educational institution in a country. The teacher quality is teacher meet the conditions that have been determined. Furthermore, teacher positions should only be entrusted to people who meet the existing requirements. One of them is having teacher competence (Suraji, 2012). 
In Indonesia, teacher competency has been regulated through the constitution of teacher and lecture number 14 of 2005. As stated in the article 8,9, and 10, the teacher is obligated to have four competencies; pedagogic, professionalism, social, and personality. Pedagogical competence is the teacher ability in managing the learning that is consisted of the understanding of the students, planning and implementing the learning, evaluating the learning result, and developing student competencies to actualize their potential (Hidayat, 2017; Mâţă, 2014). Personality competence is an educator personality who is steady, stable, mature, wise and dignified, exemplify the students, and noble. Social competence is an educator ability to communicate and interact effectively with the students, educators, education personnel, parents, and society. professional competence is an educator ability to master the learning material in the wide and in-depth scope that is likely to assist the students to achieve the expected competencies (Drovnikov et al., 2016; Sudarma, 2014).

To develop these four competencies, the government has been carried out many programs like professional teacher education or usually called Pendidikan Profesi Guru (PPG). Teachers who have passed the PPG are declared professional teachers as evidenced by a professional educator certificate. These teachers are also entitled to a teacher professional allowance in the amount of one base salary. However, several studies stated that the impact of teacher certification was not as expected. Fact that the performance of teachers who have received certification is still low (Dewanto et al., 2015). The low performance of teachers is found in (1) the low commitment of teachers in teaching and educating, (2) the low commitment of teachers to hold the profession professionally, and (3) the lack of teacher willpower to improve the professionalism, like the ability to provide teaching materials, write scientific papers in the field of study, develop learning media, have the relevance and adequate reference (Andriani et al., 2018; Murtiningsih et al., 2019; Renata et al., 2018; Aglozo et al., 2019).

\section{A Principal Role in Improving Teacher Competence}

Optimizing the role of the school principal in increasing teachers' pedagogical and professional competence is essential (Hamalik, 2010). The school principal is teacher operational staff who is assigned the task to leading a school, where the learning process is held, or a place where there is the interaction between teachers who give lessons and students who receive lessons (Wahjosumidjo, 2013). The school principal is a prime mover that which drives all of the school activities (Barlian, 2013). The leadership of the school principal will be successful if he understands the existence of the school as a complex and unique organization and can utilize the resources (Fatah, 2008) optimally. As what is said by Sharp and Walter (2003), the school principal, whether elementary or secondary, is the single most important person to a school's success. The leadership of the school principal is one of the pivotal keys of the development program of teacher capacity (Khoiruddin, 2015).

Many of research result supports the importance of the principal role in improving teacher competencies (Leithwood \& Seashore-Louis, 2011; Leithwood \& Jantzi, 2006). Hallam et al., (2015) showed that the teachers perceive the principal as a source of reassurance and may also pay more attention to their decisions and actions (Oreg \& Berson, 2011). The results of Harapan's (2017) study show that principal leadership has a significant effect on teacher performance. Besides, there is evidence that principal leadership can function to reduce job stress and uncertainty by providing meaningful emotional support and assistance (Kelchtermans et al. 2009), therefore, it can increase teacher performance (Johnson \& Birkeland, 2003; Skaalvik \& Skaalvik, 2011).

In the new education management paradigm, the school principal at least must be able to have a role as educator, manager, administrator, supervisor, leader, innovator, and motivator (abbreviated as EMASLIM) (Kurniasih, 2017; Maduratna, 2013; Mulyasa, 2013). Bellamy et al. (2007) said that principals may have the most complex job in education. The job of the school principal is increasing day by day, and will always increase according to the expected educational development, in this case, the school principal job is not only as EMASLIM, but it will continue to be developed. The school principal has a vital role because, first, the school principal is a figure who is capable of being a facilitator to achieve the purpose of education. Second, the school principal is a figure which is expected to be able to empower the potential that existed in the school (Ketut, 2015). In the context of Indonesia, the principal's role as manager, leader, and innovator is particularly salient. 
The increase of teacher pedagogical and professional competence is carried out of the optimization of the principal school role. The school principal who optimally carries out the role in increasing pedagogical competence and teacher professional competence is going to increase the learning quality, and then increase the quality of education. The role of the school principal in increasing pedagogical competence and teacher professional competence can be seen in Figure 1.

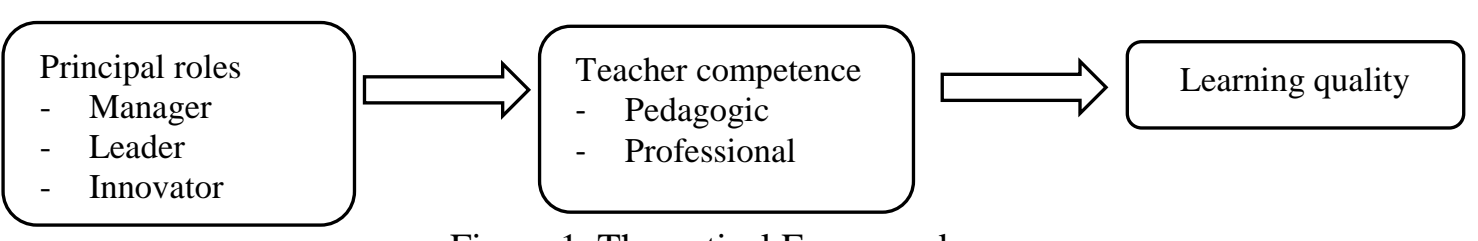

Figure 1. Theoretical Framework

\section{METHOD}

\section{Research Design}

This study is qualitative research by using a study case (Creswell, 2013). A case study approach used in this research is because the research involves contemporary events that are taught in a natural setting and the research does not interfere with the studied subject's behaviour (Gomm et al. 2000; Noor, 2008). The case studies allow the research data to be collected using a variety of methods and sources (Yin, 2006) and combine the description of event and data analysis (Denzin \& Lincoln, 2011; Reason \& Bradbury, 2001; Vandenberghe \& Kelchtermans, 2002).

\section{Participants}

The research subject was the principal and teachers in the Muhammadiyah elementary school of Macanan, Sleman, and Muhammadiyah elementary school of Al-Mujahidin, Gunungkidul, located in Special Region of Yogyakarta. Both schools were chosen because in the last few years they have rapidly developed. The development was proven by the increase of the interest of the society to send their children into this schools. Muhammadiyah elementary school of Macanan is geographically located in a rural area, precisely located at the Macanan Village, Ngemplak sub-district, Sleman Regency. Both schools reach other several surrounding districts (Interview with R1). Meanwhile, SD Muhammadiyah Al-Mujahidin Wonosari is located in a strategic area, downtown Gunungkidul Regency. Both schools have been growing rapidly in the last three years. In detail, the research subjects consisted of two principals, three teachers of Muhammadiyah elementary school of Macanan, and four teachers of Muhammadiyah elementary school of Al-Mujahidin, Wonosari. Purposive sampling technique was used for choosing the subjects of the research. To show the data representation, in addition, research subject sources are coded by R1 to R9 (respondent 1 to respondent 9).

\section{Research Data Analysis and Data Collection Technique}

The research data were collected using interview, observation, and documentation techniques. The researchers interviewed the principal twice, while teachers were interviewed once. The longest interview was conducted for 45 minutes, while the shortest was 25 minutes. Data collection was carried out in January-March 2019. In collecting data, researchers were guided by research guidelines. Research guidelines are developed based on the theoretical framework that has been developed in the theoretical framework section. The main questions focused on three principal roles as a manager, leader, and innovator. However, in the practice, the research guidelines are used flexibly so that the researchers could develop the questions profoundly in the form of an in-depth interview. The grids of the research guidelines are explained in Table 1. In addition, the data analysis in this research used an interactive model of Miles and Huberman, as seen in Figure 2.

The activities in the qualitative data analysis were carried out interactively and took place continuously so that the data was saturated. The activities in data analyzing are data collection, data simplification, data representation, and concluding. The data obtained in the field are summarised; the 
main ones are selected, and are focused on essential things. The data is systematically represented in order to be more fully and thoroughly understood among the parts; therefore, it is likely drawing the conclusions or verification. Drawing the conclusions or verification cannot be separated from researched problems.

Table 1. The Grid of the Role of the School Principal in Increasing Teacher Pedagogical and Professional Competence

\begin{tabular}{|c|c|c|}
\hline Aspect & Indicator & Evidence \\
\hline \multirow[t]{3}{*}{$\begin{array}{l}\text { The role of the school } \\
\text { principal in increasing } \\
\text { teacher pedagogical and } \\
\text { professional competence }\end{array}$} & Manager & $\begin{array}{l}\text { 1. Planning the program by detailing the needs of teachers } \\
\text { and academic staffs whos run the tasks and planning the } \\
\text { curriculum that will be implemented. } \\
\text { 2. Empowering the teachers by dividing the tasks based on } \\
\text { each teachers' ability } \\
\text { 3. Arranging the staffing organization in the school and also } \\
\text { optimizing the school resources. }\end{array}$ \\
\hline & Leader & $\begin{array}{l}\text { 1. To be an excellent example to other teachers } \\
\text { 2. To have the skills and a good personality. } \\
\text { 3. To be disciplined, honest, brave, firm, interesting. }\end{array}$ \\
\hline & Innovator & $\begin{array}{l}\text { 1. Program Innovation } \\
\text { 2. Learning Innovation } \\
\text { 3. Communication Innovation }\end{array}$ \\
\hline
\end{tabular}

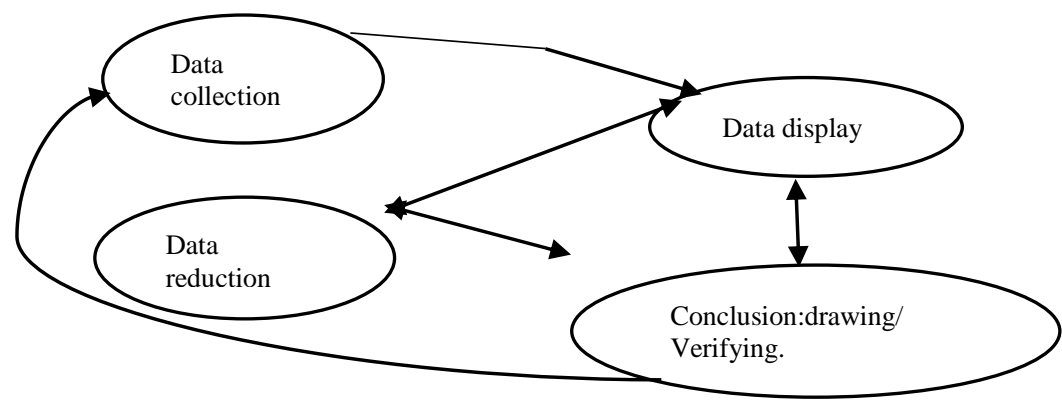

Figure 2. Interactive Analysis Model

In detail, data analysis was carried out in two steps; open coding and analytic coding. The way open coding was carried out was that the researchers read the data thoroughly and systematically (Smith et al., 2009). The researchers use side comments to identify various emerging themes and sub-themes. Analytic coding was carried out by connecting various similar codes (and solving them) to conclude the data that has been coded in the first step (Robson \& McCartan, 2016). After finishing the reading transcript along with the appeared themes, the previous themes was revised recombined, and grouped into a more complete figure (Smith et al., 2009).

\section{FINDINGS AND DISCUSSION}

\section{Findings}

This research aims to reveal the role of the school principal in increasing teacher pedagogical and professional competence. According to the analysis, three primary roles of the school principal in increasing teacher pedagogical and professional competence are the school principal as a manager, the school principal as a leader, and the school principal as an innovator. Based on the analysis of research data, it had been found three primary themes that describe the role of school principals in increasing pedagogical competence and teacher professional competence: the school principal as a manager, the school principal as a leader, as the school principal as an innovator. Accompanied relevant interview excerpts explained each theme as proofs. 


\section{The School Principal as A Manager}

The first role found in this study is the school principal as manager. The role of the school principal as a manager in increasing teacher professional competence was carried out by planning programs detailing the needs of educators and education personnel who will carry out their duties, planning the curriculum that will be implemented, and planning a policy of adding guidance and counselling subjects. In turns, the school principal assign the teacher to participate in the activities of the school visit, teacher exchange, upgrading program, training, and workshop. The principal checks the learning administration made by teachers such as learning implementation plan and learning scenario, also helping the teacher by providing the feedback and advice to fulfil or improving the administration that will be used by the teacher during learning implementation. The school principal conducts a class visit to monitor the learning process carried out by the teacher in the classroom like teacher understanding toward the students, learning implementation, the valuation of learning outcomes, and student development. Then, the next activities are monitoring and evaluating; for example, the school principal monitors the activities through supervision teams or students. Also, the school principal evaluates learning outcomes through an administration that has been reported by the teacher. In increasing teacher professional competence is by giving the assignment according to teachers' ability, such as the being vice-principal, vice-principal of curriculum, treasurer, and task on extracurricular activities. The school principal creates an organizational structure involving students' parents through the school committee and completing the necessary of facilities and infrastructure.

Based on the result of the interview of the school principal and teachers of Muhammadiyah elementary school of Macanan and Muhammadiyah elementary school of Al-Mujahidin, it is commented that the role of the school principal as a manager in increasing teacher pedagogical competence is:

"The school principal plan the program by detailing the need of the program, plan the curriculum that will be implemented, assign the teachers to take a comparative study, assign to join teacher exchange or school visit, and help the teacher to improve material content or method in learning implementation plan. Carrying a class visit and observing the teacher toward the students, learning implementation, assessment, and student development carried out by the teachers, also monitoring and evaluating." (RI).

In addition, as a manager, the increase of teacher professional competence in Muhammadiyah elementary school of Macanan and Muhammadiyah elementary school of Al-Mujahidin is conducted by:

"The school principal assigns the teacher to participate in training, training and education, pursuing study and giving the additional task to the teachers like being committee, coordinator, etc. Conduct class visits and observe the teacher's mastery of learning materials, the suitability of teaching materials, providing the exemplary based on students' daily life, as well as seeing the suitability of learning planning with the learning implementation. Also, the school principal monitors and evaluates the activities outside the school, such as teachers' activities in participating in training and seminar outside the school. The school principal asks the teachers to report their outcomes of the program in the report or cluster's teacher workgroup in the school in order to impact the other teachers." (R2).

In increasing teacher professional competence, the school principal also assigns the teacher to participate in training, seminar, or workshop. The school principal conducts regularly checking into the learning administration made by the teacher like learning implementation plan and learning scenario. The school principal also checks the material content, method, and the results to be achieved in learning. Conducting class visit, the school principal directly observes the learning process conducted by the teachers in the class like how the teachers use the learning methods, teacher mastery of learning material, the conceptual relationship between related teaching materials, application of scientific concepts to everyday life. Monitoring and evaluating, for example, the school principal asks the teachers to report their outcomes of the program in the report or cluster's teacher workgroup in the school in order to impact the other teachers. 


\section{The School Principal as A Leader}

As a leader in increasing teacher pedagogical competence, the school principal give a target to the students, such as the target to master a class so that the teachers independently attempt to improve their ability. Through the interview, R3 stated that:

"The school principal gives a target to the teachers like class mastery; therefore, the teachers independently attempt to improve their ability. The school principal also must be able to create an engaging environment, also approach others to be easier to communicate." (R3).

Additionally, the school principal conducts a briefing, and in these activities, the school principal conveys weaknesses and constraints faced by the teachers. To be a leader, the school principal must always learn new activities, read more, and experience many things, then what has been experienced is shared to the teachers through discussion regularly, he must also give the instruction or feedback to the teachers or towards what teachers are facing. Increasing teacher professional competence is carried out by providing a good example and calmly in working, also providing the motivation and reward to the education staff both morally and materially. The principal must have a personality that is honest, disciplined, trustworthy, fair, dares to make decisions, and is firm to be an example for the teachers. In addition, the school principal conduct mental, ethic, physical, and spiritual guidance.

In increasing teacher professional competence, the school principal gives a target to the students, such as the target to master a class so the teachers independently attempt to improve their ability. The school principal carries on a comparative study, in which in that activity, the teacher can imitate or adopt the excellent learning process from other schools. It is also encouraged to enroll teachers for training outside of school or hold training in schools by inviting external sources, involve teachers in outstanding teacher competitions, recommend and provide opportunities for teachers to become model teachers/instructors, provide opportunities for teachers to develop careers, and also recommend and give teacher permission for pursuing the study. As a leader, increasing teacher professional competence in Muhammadiyah elementary school of Macanan and Muhammadiyah elementary school of Al-Mujahidin was conducted by:

"Giving the target such as material mastery. The school principal also carries out mental, ethical, physical and spiritual coaching. The school principal must have honest, disciplined, trusted, fair, dare to take the decision, and firm personality so that these can be an example for the teachers." (R4)

\section{The School Principal as An Innovator}

As an innovator in increasing teacher pedagogical competence, the school principal innovates the learning process, in which the learning that previously only use the books as sources is innovated by electronic media-based learning, and the seating arrangements must always change every week. Giving a reward such as a certificate of merit or charter to the best performing teachers is also needed to motivate other teachers to improve their performance, either in the school or outside school. Facilitating classes such as providing teach-ing media, necessary facilities such as LCDs, LEDs, internet networks, and other facilities needed by teachers to carry out the learning process in the classroom is also a good idea. Increasing teacher pedagogical competence is carried out by innovation of school program and teacher performance programs like GSM (Gerakan Sekolah Menyenangkan/Fun School Movement) and a creative school. Facilitating the whole necessary required by the teacher to participate in the activities that have been arranged by the school, such as transportation, facilities and infrastructure, equipment required during the activity, and allowance after the activities are finished.

As an innovator, increasing teacher professional competence in Muhammadiyah elementary school of Macanan and Muhammadiyah elementary school of Al-Mujahidin was conducted by:

"Making the updates or changes of the learning such as GSM (Gerakan Sekolah Menyenangkan/Fun School Movement) and the seating arrangements must always change every week. Giving the motivation like reward and punishment to the teachers and education staffs, such as giving a reward for the best teacher in class management. Facilitating the need of the teachers in learning implementation, such as facilitating the class with LCD, LED, and internet access to encourage and ease the teachers to manage their class." (R1). 
As an innovator, increasing teacher professional competence in Muhammadiyah elementary school of Macanan and Muhammadiyah elementary school of Al-Mujahidin was conducted by:

"the renewal program like creative school, in which in every year the program must be innovated and different to the previous program in the last year. Giving a reward to the outstanding teacher and well-performed teacher. Facilitating the whole necessary of learning required by the teacher to participate in training, seminar, or workshop. The facilities given are transportation, the needs required during the activities, and allowance after the program finished." (R2).

In addition, based on the interview of the school principal and the teacher of Muhammadiyah elementary school of Macanan and Muhammadiyah elementary school of Al-Mujahidin, the success of the school principal role in increasing teacher pedagogical and professional competence is stated that:

"The teachers felt the success of the increase of teacher pedagogical and professional competence. The teacher becomes more understand the good learning, learning administration, learning process, and learning evaluation. The success of increasing teacher pedagogic competence and professional competence can be seen in the learning process that is being carried out by the teacher. The success of increasing the teacher pedagogic competence and professional competence can be seen from the results of the supervision of the school principal. Also, the success of increasing the teacher pedagogic competence and professional competence can be seen from the impact of the learning carried out by the teacher, like student achievement and school achievement." (R5, R6).

\section{The Impact of the Role of the School Principal toward the Increase of Teacher Pedagogical and Professional Competence}

The teachers felt the success of the increase of teacher pedagogical and professional competence. The teacher becomes more understand good learning, learning administration, learning process, and learning evaluation. The success of the increase of teacher pedagogic and professional competence can be seen from the learning process conducted by the teacher in the class, in which the indicator of pedagogic competence like teacher understanding toward students, learning design and implementation, the evaluation of learning outcomes, student development, and teacher professional competence like teacher ability in the mastery of learning material in-depth and broadly that encompassing (a) concept, structure, and scientific/technology/art methods that are coherent with learning materials; (b) learning material existed in the school curriculum (c) concept relationship among related subjects; (d) the application of scientific concept in the daily life; and (e) teachers have done a professional competition in a global context while preserving national values and culture. Furthermore, the success of the increase of teacher pedagogical and professional competence also can be seen in the impacts of the learning process conducted by the teachers, such as school achievement, teacher achievement, and student achievement.

In the learning process conducted by the teachers in both elementary schools, the indicator of teacher pedagogical and professional competence are well-contained in the learning process. The indicators are learning plan, learning management, the understanding the students, learning implementation, the evaluation learning outcomes, student development, the use of the method, the relationship between the concepts and related learning materials, and the scientific application in the students' life that has been conducted by the teachers well.

The learning implementation plan includes the need for identification, competence, and arrangement of the learning program. The teacher starts learning by greeting and praying, and then the teacher conducts pre-test to deliver the material and reminds the students of the previous material. In the stage of the learning process, the teacher opens the lesson clearly and communicatively, conveying the learning objectives concisely and clearly, mastery of the material is smooth, giving actual examples, and answering the students' questions correctly. The material is presented based on the objectives and adjusted to the students' abilities, the use of methods is according to the objectives and material, the use of effective methods and is aimed at students, the props used are in accordance with the material, then evaluated by giving the questions or tasks. 
The understanding toward the students is done by observing the students when learning class, the things observed are the level of student intelligence, student creativity, student physical condition, and students' cognitive growth and development. Learning management conducted out to enhance student liveliness or involvement in the learning process. The management of student liveliness is by creating a discussion group or question and answer. The evaluation of learning outcomes is conducted during and the end of the learning process by providing the questions and answer to the students. The learning evaluation is also conducted using daily tests, monthly tests, and semester exams.

Developing the students is carried out through extracurricular, material enrichment and remedial, or guidance and counselling. The use of the method is customized by learning material; however, when the researchers observed the learning process, the method that mostly used are discussion as well as question and answer. In the thematic learning, the learning material is presented by linking material to one another. The application of scientific concept with daily life is carried out by giving an example based on daily student life and is related to surroundings. The method used is carried out so that the students can interpret the learning and apply them to their life.

Based in the observation result from the documentation of Muhammadiyah elementary school of Macanan and Muhammadiyah elementary school of Al-Mujahidin, the success of the teacher pedagogical and professional competence can be observed from the impacts of the learning, such as student achievement and school achievement. Muhammadiyah elementary school of Al-Mujahidin is one of the exemplary school in Gunungkidul regency.

\section{Discussion}

This study aims to reveal the role of principals in improving teacher pedagogical and professional competence in both Muhammadiyah schools. From the data analysis, it is found that the principals have a role as a manager, leader, and innovator in improving pedagogical competency and teacher professional competency.

The first finding shows that the principals have implemented their role as a manager well in the researched schools. The principal role as a manager was carried out by planning the program by detailing the needs of the educators and education personnel, planning the curriculum, and planning a policy of adding the subjects of counselling guidance. This description is in line with Barlian (2013) that the school principal as a manager arranges the school program, arranges staffing organization in the school, drives the staff (teachers and education staff), and optimize school resources. The early research result by Rusmawati (2013) shows that the school principal acts as a manager by empowering teachers through collaboration and involving teachers in decision making. The school principal is also responsible on the continuity of all of the activities and administration in the school, such as curriculum management, student administration, personnel administration, facility and infrastructure administration, and archive and financial administration (Fitrah, 2017; Maduratna, 2013). As a manager, the school principal must be able to supervise teachers' work, in this case, the supervision is to enhance the supervision and control toward teachers and staffs in order to increase their performance.

The second finding is that the principals had a role as a leader. In carrying out their role, the principals give targets to teachers about class mastery and doing briefing. The aforementioned description is in line with the previous research by Kurniasih (2017) and Maduratna (2013) who said that the school principal must be capable of creating a conducive school climate, gives advice to the school residents, encourage the education staffs, and also implement an interesting learning model. The personality of the school principal as a leader is reflected in the characteristics of honesty, selfconfidence, responsibility, the courage to take risks and decisions, big-hearted, stable emotions, and being role models. The principal must always strive to improve the quality of learning carried out by teachers, in this case, the experience factor will greatly influence, especially in supporting to form the understanding of the academic staff towards the implementation of their duties. The principal must also provide opportunities for teachers to increase their knowledge and skills by pursuing a higher level of education (Mulyasa, 2013).

The third finding is as an innovator. In carrying out the principal role, the principal emphasized the importance of information technology-based learning innovation and classroom management. Mulyasa (2013) said that the school principal, as an innovator, must be able to figure out, find, and 
implement the various renewal in the classroom. The school principal must also have the right strategy to motivate the education staffs in performing their various tasks and functions. The school principal has to attempt to use the award appropriately, effectively, and efficiently to avoid negative impacts that may arise. The research of Deesomsak et al. (2014) stated that the involvement of STEM in the learning process could facilitate STEM teacher to be more innovative and relevant pedagogically. The results also support previous findings which state that school principals as innovators must be able to plan, coordinate the activities, supervise, evaluate the program, make decisions, regulate the learning process, organize administration, and also manage administration, students, workforce, infrastructure, and finance (Sabirin, 2012). The principal is also required to be able to manage the school, and this ability will emerge if the principal widely opens himself to dynamics and changes (Purwoatmodjo, 2011).

The three roles of the principal have an impact on the competence of teachers in carrying out meaningful and fun learning, classroom management, the use of information technology in learning, mastery of the development of students and subjects. Sudarma (2014) stated that the success of the teacher pedagogical and professional competence could be seen from the teacher ability in managing the learning including teacher understanding toward the student, learning design and implementation, the evaluation of learning outcomes, and developing the students to actualize various competence they have, and teacher ability to master in-depth and broad teaching material encompassing (1) concept, structure, and scientific/technology/art method that are coherent with the learning material; (2) teaching materials in the learning curriculum; (3) the relationship between related subjects; (4) the application of scientific concepts in the daily life; and (5) professional competition in the global contexts by preserving national values and culture. In general, the findings reaffirm the positive impact of the principal role on improving teacher competence, especially pedagogic and professional competence (Boon, 2017; Gumus, 2013; Sehgal et al., 2017).

\section{CONCLUSION}

The role of the school principal in increasing teacher pedagogical and professional competence in Muhammadiyah elementary school of Macanan and Muhammadiyah elementary school of AlMujahidin is, first, as a manager, the school principal divides the task according to teacher ability and assigns teachers in turns to participate in training, seminars, or workshops. Supervising through class visits during class hours, controlling through monitoring and evaluation. Second, as a leader, the school principal must have the ability to educate the teachers, provides mental, ethic, physic, and spiritual guidance. Third, as an innovator, the school principal makes the renewal of the learning, school program, and teacher work program. Also, providing the motivation and facilitating the needs of the teachers to participate in the activities of the improvement of the teacher competence. The findings reaffirm the positive impact of the principal role on improving teacher competence, especially pedagogic and professional competence. The application of collaborative leadership, close to teachers, and oriented to the quality of learning will have an impact on improving teacher competence. The results of this study can become a reference enrichment regarding one of the ways adopted by education policyholders in Indonesia in formulating teacher competency development programs. The limitation of this study is that the research subjects consist of only two private schools in Yogyakarta, even though both school adequately portray the geographical diversity of the school origin so that the research result cannot represent school condition in Yogyakarta in general. Therefore, future research requires to involve more a more profound range of research subjects and a wider range of the areas. Quantitative research examining the correlation of principal leadership towards increasing pedagogical and professional competence that also seems necessary.

\section{ACKNOWLEDGMENT}

The researchers thank Muhammadiyah elementary school of Macanan and Muhammadiyah elementary school of Al-Mujahidin who help to conduct this research. Besides, the researchers deliver gratitude to all of the lecturers of the master study program of Educational Management of Universitas Ahmad Dahlan. 


\section{DAFTAR PUSTAKA}

Aglozo, E. Y., Akotia, C. S., Osei-Tutu, A., \& Annor, F. (2019). Spirituality and subjective wellbeing among Ghanaian older adults: Optimism and meaning in life as mediators. Aging and Mental Health, 25(2), 1-10. https://doi.org/10.1080/13607863.2019.1697203

Andriani, S., Kesumawati, N., \& Kristiawan, M. (2018). The influence of the transformational leadership and work motivation on teachers performance. International Journal of Scientific and Technology Research, 7(7), 19-29. Retrieved from https://www.ijstr.org/finalprint/july2018/The-Influence-Of-The-Transformational-Leadership-And-WorkMotivation-On-Teachers-Performance.pdf

Barlian, I. (2013). Manajemen berbasis sekolah menuju sekolah berprestasi. Erlangga Groups.

Bellamy, G. T., Fulmer, C. L., Murphy. M. J., \& Muth, R. (2007). Principal accomplishments: How school leaders succeed. Teachers College Columbia University.

Boon, Y. (2017). The role of headmaster to improve pedagogic competence of teachers in vocational high school. Technics Technologies Education Management, 12(3), 207-213. https://doi.org/10.31227/osf.io/uqsxk

Boyce, J., \& Bowers, A. J. (2018). Toward an evolving conceptualization of instructional leadership as leadership for learning: Meta-narrative review of 109 quantitative studies across 25 years. Journal of Educational Administration, 56(2), 161-182. https://doi.org/10.1108/JEA-062016-0064

Çalik, T., Sezgin, F., Kavgaci, H., \& Kilinç, A. Ç. (2012). Examination of relationships between instructional leadership of school principals and self-efficacy of teachers and collective teacher efficacy. Kuram ve Uygulamada Egitim Bilimleri, 12(4), 2498-2504.

Creswell, J. W. (2013). Qualitative inquiry and research design: Choosing among five approaches (3rd ed.). Sage.

Deesomsak, R., Paudyal, K., \& Pescetto, G. (2014). Durham research online woodlands. In Critical Studies on Security, 2(2), 210-222.

Denzin, N. K., \& Lincoln, Y. S. (Eds.). (2011). The SAGE handbook of qualitative research. Sage.

Dewanto, D. H., Erviantono, T., \& Winaya, I. K. (2015). Pengaruh sertifikasi terhadap kinerja guru di SMA N 1 Gianyar. Citizen Charter, 1(1), 1-10. Retrieved from https://ojs.unud.ac.id/index.php/citizen/article/view/23819

Djamarah, S. B. (2010). Guru dan anak didik dalam interaksi edukatif(3rd ed.). PT Asdi Mahasatya.

Domsch, G. D. (2009). A study investigating relationships between elementary principals' and teachers' self-efficacy and student achievement. Saint Louis University.

Drovnikov, A. S., Nikolaev, E. L., Afanasev, A. S., Ivanov, V. N., Petrova, T. N., Tenyukova, G. G., Maksimova, N. L., \& Povshednaya, F. V. (2016). Teachers professional competence assessment technology in qualification improvement process. International Review of Management and Marketing, 6(1), 111-115. Retrieved from http://www.econjournals.com/index.php/irmm/article/view/1756

Fatah, N. (2008). Landasan manajemen pendidikan (8th ed.). PT Remaja Rosdakarya.

Fitrah, M. (2017). Peran kepala sekolah dalam meningkatkan mutu pendidikan. Jurnal Penjaminan Mutu, 3(1), 31-42. https://doi.org/10.25078/jpm.v3i1.90

Gomm, R., Hammersley M., \& Foster, P. (Eds.). (2000). Case study method: Key issues, key texts. Sage.

Gumus, S. (2013). The effects of teacher- and school-level factors on teachers participation in professional development activities: The role of principal leadership. Journal of 
110 - Jurnal Akuntabilitas Manajemen Pendidikan

International Education Research (JIER), 9(4), 371-380. https://doi.org/10.19030/jier.v9i4.8089

Hallam, P. R., Smith, H. R., Hite, J. M., Hite, S. J., \& Wilcox, B. R. (2015). Trust and collaboration in PLC teams: Teacher relationships, principal support, and collaborative benefits. NASSP Bulletin, 99(3), 193-216. https://doi.org/10.1177/0192636515602330

Hamalik, O. (2010). Pendidikan guru beradarkan pedekatan kompetensi (7th ed.). Bumi Aksara.

Harapan, R. (2017). Pengaruh kepemimpinan kepala sekolah terhadap kinerja guru di MAN 2 Padangsidimpuan. Al-Muaddib: Jurnal Ilmu-Ilmu Sosial \& Keislaman, 1(1), 19-28. https://doi.org/10.31604/muaddib.v1i1.108

Hefner, R. W. (2008). Api pembaharuan Kiai Ahmad Dahlan. Multi Pressindo.

Hidayat, S. (2017). Pengembangan guru profesional (1st ed.). PT Remaja Rosdakarya.

Hulpia, H., Devos, G., \& van Keer, H. (2011). The relation between school leadership from a distributed perspective and teachers' organizational commitment: Examining the source of the leadership function. Educational Administration Quarterly, 47(5), 728-771. https://doi.org/10.1177/0013161X11402065

Johnson, S. M., \& Birkeland, S. E. (2003). Pursuing a "sense of success": New teachers explain their career decisions. American Educational Research Journal, 40(3), 581-617. https://doi.org/10.3102/00028312040003581

Kelchtermans, G., Ballet, K., \& Piot, L. (2009). Surviving diversity in times of performativity: Understanding teachers' emotional experience of change. In P. Schutz \& M. Zembylas (Eds.), Advances in teacher emotion research (pp. 215-232). Springer.

Ketut, J. (2015). Menjadi kepala sekolah yang profesional (1st ed.). CV. Budi Utama.

Khoiruddin, B. (2015). Pengembangan kapasitas guru (1st ed.). PT Pustaka Alvabet.

Kin, T. M., Kareem, O. A., Nordin, M. S., \& Bing, K. W. (2018). Principal change leadership competencies and teacher attitudes toward change: The mediating effects of teacher change beliefs. International Journal of Leadership in Education, 21(4), 427-446. https://doi.org/10.1080/13603124.2016.1272719

Kurniasih, E. (2017). Peran kepala sekolah dalam meningkatkan kompetensi guru. Indonesian Journal of Education Management \& Administration Review, 1(1), 11-17. Retrieved from https://jurnal.unigal.ac.id/index.php/ijemar/article/view/932

Lassila, E. T., Timonen, V., Uitto, M., \& Estola, E. (2017). Storied emotional distances in the relationships between beginning teachers and school principals. British Educational Research Journal, 43(3), 486-504. https://doi.org/10.1002/berj.3280

Leithwood, K., \& Jantzi, D. (2006). Transformational school leadership for large-scale reform: Effects on students, teachers, and their classroom practices. School Effectiveness and School Improvement, 17(2), 201-227. https://doi.org/10.1080/09243450600565829

Leithwood, K., \& Seashore-Louis, K. (2011). Linking leadership to student learning. John Wiley \& Sons.

Liu, S., \& Hallinger, P. (2018). Principal instructional leadership, teacher self-efficacy, and teacher professional learning in China: Testing a Mediated-Effects Model. Educational Administration Quarterly, 54(4), 501-528. https://doi.org/10.1177/0013161X18769048

Maduratna, M. (2013). Peranan kepemimpinan kepala sekolah dalam meningkatkan efektivitas kerja guru dan Sekolah Dasar 015 Samarinda. EJournal Administrasi Negara, 1(1), 70-84. Retrieved from https://ejournal.ap.fisip-unmul.ac.id/site/?p=603 
Majid, A. (2014). Pelajaran dan pembelajaran pendidikan agama Islam (2nd ed.). PT Remaja Rosdakarya.

Marzano, R. J., Waters, T., \& McNulty, B. A. (2001). School leadership that works: From research to results. ASCD.

Mâţ̌ă, L. (2014). Pedagogical competencies for mother-tongue teacher education. Kuram ve Uygulamada Egitim Bilimleri, 14(1), 341-352. https://doi.org/10.12738/estp.2014.1.1723

Mulyasa, E. (2013). Menjadi kepala sekolah profesional (12th ed.). PT. Remaja Rosdakarya.

Murtiningsih, M., Kristiawan, M., \& Lian, B. (2019). The correlation between supervision of headmaster and interpersonal communication with work ethos of the teacher. European Journal of Education Studies, 6(1), 246-256. Retrieved from https://oapub.org/edu/index.php/ejes/article/view/2398

Muttaqin, T., Wittek, R., Heyse, L., \& van Duijn, M. (2019). The achievement gap in Indonesia? Organizational and ideological differences between private Islamic schools. School Effectiveness and School Improvement, 31(2), 1-31. https://doi.org/10.1080/09243453.2019.1644352

Naim, N. (2016). Menjadi guru inspiratif memberdayakan dan mengubah jalan hidup siswa (5th ed.). Pustaka Pelajar.

Nasution, I. (2011). Kompetensi guru dan peranan kepala sekolah. VISIPENA, 2(2), 51-57. https://doi.org/10.46244/visipena.v2i2.46

Nemet, M. B. (2018). A correlation between teachers' social and pedagogical competences and school culture. Sodobna Pedagogika/Journal of Contemporary Educational Studies, 69(3), 142-155. Retrieved from https://www.sodobna-pedagogika.net/en/articles/03-2018_acorrelation-between-teachers-social-and-pedagogical-competences-and-school-culture/

Noor, K. B. M. (2008). Case study: A strategic research methodology. American Journal of Applied Sciences, 5(11), 1602-1604. Retrieved from https://thescipub.com/abstract/10.3844/ajassp.2008.1602.1604

Oreg, S., \& Berson, Y. (2011). Leadership and employees'reactions to change: The role of leaders' personal attributes and transformational leadership style. Personnel Psychology, 64(3), 627659. https://doi.org/10.1111/j.1744-6570.2011.01221.x

Paletta, A., Alivernini, F., \& Manganelli, S. (2017). Leadership for learning: The relationships between school context, principal leadership and mediating variables. International Journal of Educational Management, 31(2), 98-117. https://doi.org/10.1108/IJEM-11-2015-0152

Player, D., Youngs, P., Perrone, F., \& Grogan, E. (2017). How principal leadership and person-job fit are associated with teacher mobility and attrition. Teaching and Teacher Education, 67, 330-339. https://doi.org/10.1016/j.tate.2017.06.017

Qian, H., \& Walker, A. (2013). How principals promote and understand teacher development under curriculum reform in China. Asia-Pacific Journal of Teacher Education, 4(1), 304-315. https://doi.org/10.1080/1359866X.2013.809050

Reason, P., \& Bradbury, H. (Eds.). (2001). Handbook of action research: Participative inquiry and practice. Sage.

Renata, R., Wardiah, D., \& Kristiawan, M. (2018). The influence of headmaster's supervision and achievement motivation on effective teachers. International Journal of Scientific and Technology Research, 7(6), 44-49. Retrieved from https://www.ijstr.org/finalprint/june2018/The-Influence-Of-Headmasters-Supervision-And-Achievement-MotivationOn-Effective-Teachers.pdf

Robson, C., \& McCartan, K. (2016). Real world research (4th ed.). Wiley. 
Rusmawati, V. (2013). Peran kepemimpinan kepala sekolah dalam upaya meningkatkan disiplin kerja guru pada SDN 018 Balikpapan. EJournal Administrasi Negara, 1(2), 395-409. Retrieved from https://ejournal.ap.fisip-unmul.ac.id/site/?p=704

Sabirin, S. (2012). Perencanaan kepala sekolah tentang pembelajaran. Jurnal Tabularasa PPS UNIMED, 9(1), 111-128.

Sehgal, P., Nambudiri, R., \& Mishra, S. K. (2017). Teacher effectiveness through self-efficacy, collaboration and principal leadership. International Journal of Educational Management, 31(4), 505-517. https://doi.org/10.1108/IJEM-05-2016-0090

Setiawan, F. (2008). Pendidikan Muhammadiyah: Antara cita dan fakta. Tajdidukasi: Jurnal Penelitian Dan Kajian Pendidikan Islam, 1(1), 25-40. Retrieved from https://tajdidukasi.or.id/index.php/tajdidukasi/article/view/9

Sharp, W. L., \& Walter, J. K. (2003). Principal as school manager (2nd ed.). Library of Congress Cataloging-in-Publication Data.

Skaalvik, E. M., \& Skaalvik, S. (2011). Teacher job satisfaction and motivation to leave the teaching profession: Relations with school context, feeling of belonging, and emotional exhaustion. Teaching and Teacher Education, 27(6), 1029-1038. https://doi.org/10.1016/j.tate.2011.04.001

Smith, J. A., Flowers, P., \& Larkin, M. (2009). Interpretative phenomenological analysis: Theory, method, and research. Sage.

Sudarma, M. (2014). Profesi guru: Dipuji, dikritisi, dan dicaci (1st ed.). Rajawali.

Sumintono, B. (2017). Penyiapan dan pengembangan kepala sekolah di Indonesia dulu dan sekarang. Kilas Pendidikan, 7, 8-10.

Purwoatmodjo, S. D. (2011). Organisasi terhadap kepuasan kerja dan kinerja guru SMP di wilayah Sub Rayon 04 Kabupaten Demak. Analisis Manajemen, 5(1), 16-29. Retrieved from https://jurnal.umk.ac.id/index.php/JAM/article/view/12/11

Suraji, I. (2012). Urgensi kompetensi guru. Edukasia Islamika, 10(2), 236-254.

Tschannen-Moran, M. (2009). Fostering teacher professionalism in schools. Educational Administration Quarterly, 45(2), 217-247. https://doi.org/10.1177/0013161x08330501

Usman, M. U. (2013). Menjadi guru profesional (27th ed.). PT. Remaja Rosdakarya.

Vandenberghe, R., \& Kelchtermans, G. (2002). Leraren die leren om professioneel te blijven leren: Kanttekeningen over context [Teachers who learn to continue to learn professionally: Contextual comments]. Pedagogische Studien, 79(4), 339-351. Retrieved from https://pedagogischestudien.n1/search?identifier $=616508$

Wahjosumidjo, W. (2013). Kepemimpinan kepala sekolah (1st ed.). PT Rajagrafindo Persada.

Yin, R. K. (2006). Case study methods. In J.L. Green, G. Camilli, \& P. B. Elmore (Eds.), Handbook of complementary methods on educational research (pp. 111-122). American Educational Research Association.

Zheng, X., Yin, H., \& Li, Z. (2019). Exploring the relationships among instructional leadership, professional learning communities and teacher self-efficacy in China. Educational Management Administration and Leadership, 47(6), 843-859. https://doi.org/10.1177/1741143218764176 